ARCHITECTURAL HISTORY

\title{
JOURNAL OF THE SOCIETY OF ARCHITECTURAL
} HISTORIANS OF GREAT BRITAIN * VOLUME $4 * 1961$. 


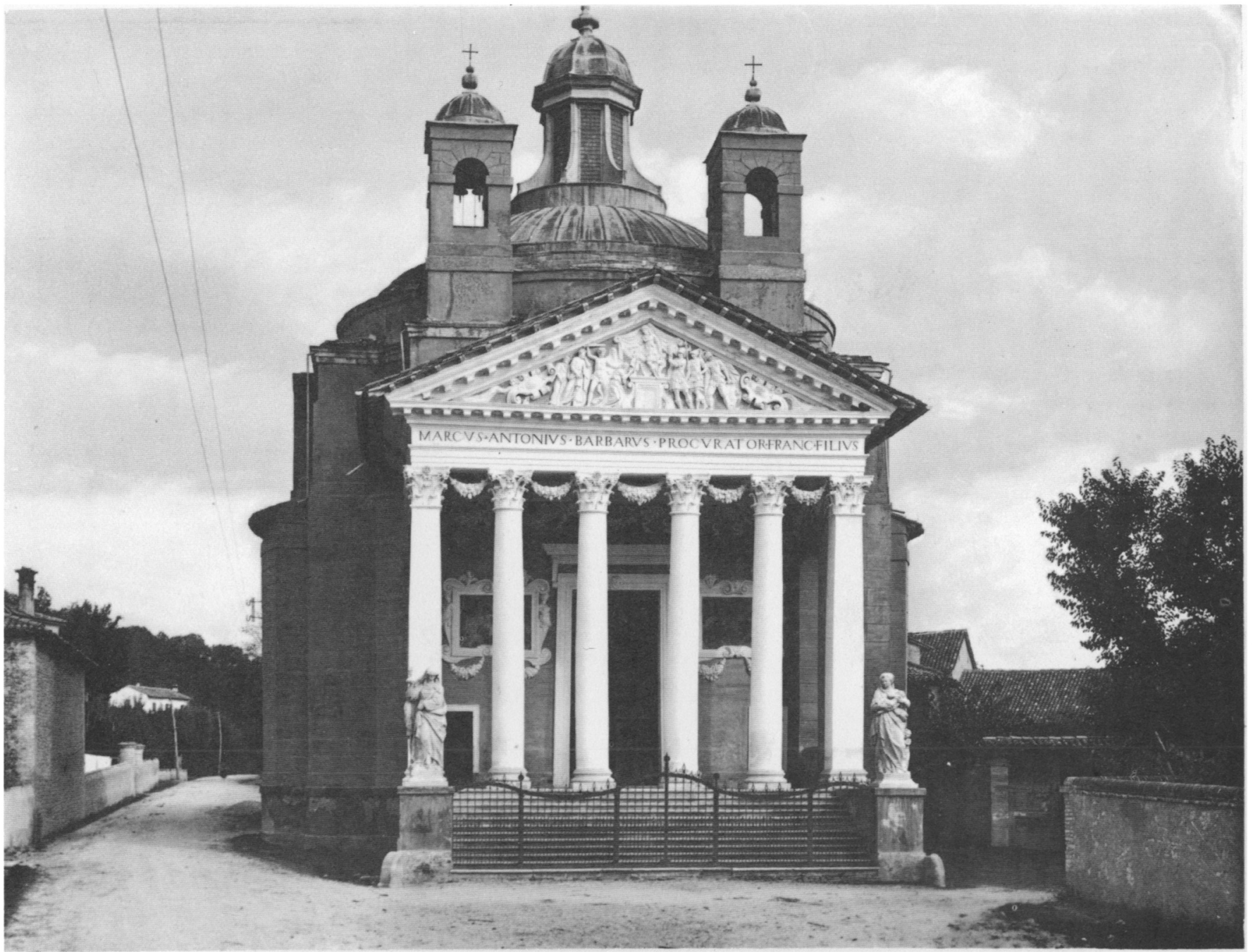

Pl. I. Maser. Chapel, Palladio, I560s (Alinari; 12339) 


\section{ARCHITECTURAL HISTORY}

\section{THE JOURNAL OF THE \\ SOCIETY OF ARCHITECTURAL HISTORIANS OF GREAT BRITAIN}

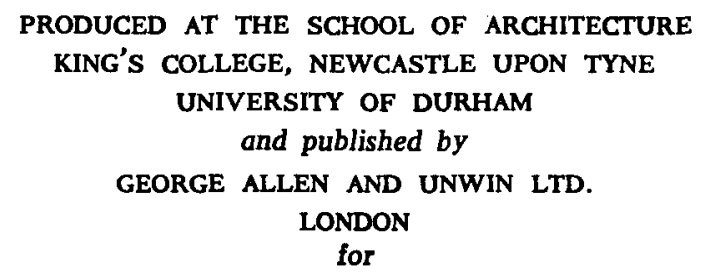

THE SOCIETY OF ARCHITECTURAL HISTORIANS OF GREAT BRITAIN I96I 


\title{
EDITORIAL COMMITTEE
}

Bruce Allsopp Howard Colvin F. Fielden
J. Quentin Hughes

F. I. Jenkins

Sir John Summerson

J. P. West-Taylor (Editor)

Set in Pilgrim 10 on 11 point by

\author{
NORTHUMBERLAND PRESS LIMITED \\ GATESHEAD \\ and printed by \\ KING'S COLLEGE PRINTING SECTION \\ NEWCASTLE UPON TYNE \\ KCPS 13925006.61
}




\section{CONTENTS}

Page

Officers and Executive Committee for 1960-61 Supporting Institutions $\quad 7$

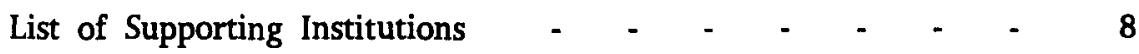

Thoresby House, Nottinghamshire, by John Harris - - - II

Temple Fronts in neo-classical Italy, by Carroll Meeks - - $\quad$ - 23

Henry Bell of King's Lynn, by H. M. Colvin and L. M. Wodehouse $4 \mathrm{I}$

The Inception of the English Railway Station, by A. A. Arschavir 63

Paxton and the Great Stove, by G. F. Chadwick - - - $\quad$ - 77

Report on the Oxford Conference - - - - - - $\quad$ - 93

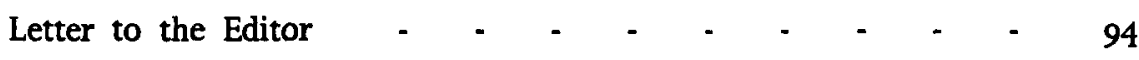

Book Reviews - $\quad$ - $\quad$ - $\quad$ - $\quad$ - $\quad$ - $\quad$ - $\quad$ - $\quad$ - 95

Supplement: Measured drawings of The Customs House at King's Lynn, by L. M. Wodehouse

Measured drawings of Albert Dock Warehouses at Liverpool by John Waldron 
Correspondence concerning the Society should be addressed to:

The Secretary or The Treasurer,

Society of Architectural Historians of Great Britain, The School of Architecture,

The University, Manchester I3.

Correspondence concerning the Journal should be addressed to :

The Editor,

Society of Architectural Historians of Great Britain, The Institute of Advanced Architectural Studies, Micklegate,

York. 